\title{
MOTIVASI, LINGKUNGAN KERJA DAN DUKUNGAN ATASAN SEBAGAI FAKTOR YANG MEMPENGARUHI KEMANDEGAN KARIR GURU IPS SMA/ MA/ SMK NEGERI DI KOTA TEGAL
}

\author{
Neni Hendaryati, M.Pd ${ }^{1}$ \\ Dosen Prodi Pendidikan Ekonomi FKIP Universitas Pancasakti Tegal \\ (Email : neni.hendaryati@yahoo.co.id)
}

\begin{abstract}
Abstrak : Karir guru merupakan posisi atau jabatan yang diduduki selama ia menekuni profesi keguruan. Data dari Dinas Pendidikan Kota Tegal Tahun 2015 terdapat 1.253 orang guru golongan IV, dengan rincian 2 orang guru golongan IV/c, 17 orang guru golongan IV/b dan 1.234 orang guru masih bergolongan IV/a. Adapun guru IPS SMA/MA/SMK di Kota Tegal yang menduduki golongan IV/b hanya 2 orang dan 57 guru masih berada di golongan IV/a dengan rentang waktu kemandegan karir lebih dari 8 tahun. Tertundanya kepangkatan guru inilah yang menjadi dasar pemikiran melakukan penelitian terhadap kemandegan karir guru IPS SMA/ MA/ SMK Negeri di Kota Tegal dan melakukan analisis yang mendalam terhadap faktor tersebut.
\end{abstract}

Ada 3 faktor kuat yang diduga sangat berpengaruh terhadap kemandegan karir guru yaitu, (1) motivasi; (2) lingkungan kerja; (3) dukungan atasan. Penelitian ini menggunakan pendekatan korelasional asosiatif, metode yang digunakan bersifat ex post facto dengan populasi 59 guru IPS SMA/MA/SMK Negeri yang berstatus PNS. Populasi yang kurang dari 100 mengakibatkan populasi dalam penelitian ini sekaligus menjadi sampel penelitian. Data dianalisis dengan SPSS for windows vs 15 dengan hasil bahwa motivasi, lingkungan kerja dan dukungan atasan secara simultan berpengaruh terhadap kemandegan karir guru IPS SMA/MA/SMK Negeri di Kota Tegal.

Disarankan bagi Dinas Pendidikan Kota Tegal, hendaknya selalu menghimbau agar senantiasa tertib administrasi, pengembangan sikap profesionalisme sehingga guru termotivasi untuk mengembangkan karirnya dengan baik.

Kata kunci: motivasi, lingkungan kerja, dukungan atasan, kemandegan karir.

${ }^{1}$ Neni Hendaryati adalah Dosen Prodi Pendidikan Ekonomi FKIP Universitas Pancasakti Tegal 
Abstract : A teacher career is a positions occupied during he pursue the teaching profession. Data from Department of Education Tegal City on 2015 there were 1.253 teachers in class IV, consist of 2 teachers in class IV/c, 17 teachers class IV/b and 1.234 teachers are still in IV/a. As for social teacher of SMA/MA/SMK in Tegal is occupying in class IV/b only 2 teachers and 57 teachers were still in class IV/a with a span of career stagnation more than 8 years. The delay rank of teacher is the basis of thinking do research on stagnation career social teacher of SMA/MA/SMK in Tegal and do analysis of such factors.

There are 3 powerful factors which we think is very influential on stagnation career teacher such as, (1) motivation; (2) the work environment; (3) support the boss. This research uses an associative correlate approach; the method used is ex post facto with population of 59 social teachers in SMA/MA/SMK of civil servants. Population less than 100 resulted in population in this research as well as a sample. Data were analyzed with SPSS for windows vs. 15 with the result that the teacher of motivation, work environment and support the boss simultaneously influence the stagnation career social teacher of SMA/MA/SMK in Tegal City.

Based on the research, it is advisable that Department of Education Tegal City should be motivated in order to orderly administration, development of teacher professionalism so that teachers are motivated to develop his career well.

Keywords: motivation, work environment, support the boss, stagnation career.

\section{PENDAHULUAN}

Karir dalam penelitian ini lebih menekankan pada pengembangan profesi secara berkelanjutan. Menurut PANRB No 16 tahun 2009 pengembangan profesi berkelanjutan yaitu pengembangan kompetensi Guru yang dilaksanakan sesuai dengan kebutuhan, bertahap, berkelanjutan untuk meningkatkan profesionalitasnya. Dalam arti sempit, pengembangan profesi guru berkaitan dengan kenaikan kepangkatan guru. Kenaikan pangkat seorang guru dinilai dari angka kredit yang harus dipenuhi.

Idealnya, seorang guru mengajukan kenaikan pangkat secara berkesinambungan dan berkala. Kenaikan pangkat bisa diusulkan mulai 2 sampai 4 tahun sekali. Namun, tidak semua guru mampu mengembangkan karirnya dengan baik, karir mereka terhenti pada tingkat tertentu. Menurut Allen at all, (1999:137) titik kemandegan dalam karir didefinisikan sebagai 
satu titik dimana kemungkinan tambahan promosi secara hierarkis sangat rendah.

Berdasarkan data guru yang diperoleh dari Dinas Pendidikan Kota Tegal terdapat 1.253 orang guru golongan IV, dengan rincian 2 orang guru golongan IV/c, 17 orang guru golongan IV/b dan 1.234 orang guru masih bergolongan IV/a. Adapun untuk guru IPS SMA/MA/SMK di Kota Tegal yang menduduki golongan IV/b hanya 2 orang dan 57 guru masih berada di golongan IV/a dengan rentang waktu kemandegan karir lebih dari 8 tahun. Tingginya angka guru yang terhenti pada pangkat dan golongan tertentu membuat karir guru terasa sangat memberatkan bagi sebagian besar guru. Padahal, kualifikasi pendidikan minimal guru IPS SMA/ MA/ SMK adalah S1, seperti syarat yang diamanatkan dalam undang-undang.

Dari banyaknya faktor yang dianggap berpengaruh terhadap kemandegan karir guru, ada tiga faktor yang diduga paling berpengaruh terhadap kemandegan karir guru antara lain: (1) motivasi; (2) lingkungan kerja dan (3) dukungan atasan. Mandegnya kepangkatan guru inilah yang menjadi dasar pemikiran untuk melakukan penelitian tentang "Motivasi, Lingkungan Kerja, dan Dukungan Atasan sebagai Faktor yang Mempengaruhi Kemandegan Karir Guru IPS SMA/ MA/ SMK Negeri di Kota Tegal.

Tujuan dari penelitian ini adalah sebagai berikut :

1. Mengetahui besarnya pengaruh Motivasi, Lingkungan Kerja, dan Dukungan Atasan secara bersama-sama terhadap Kemandegan Karir Guru IPS SMA/ MA/ SMK Negeri di Kota Tegal?

2. Mengetahui besarnya pengaruh Motivasi terhadap Kemandegan Karir Guru IPS SMA/ MA/ SMK Negeri di Kota Tegal?

3. Mengetahui besarnya pengaruh Lingkungan Kerja terhadap Kemandegan Karir Guru IPS SMA/ MA/ SMK Negeri di Kota Tegal?

4. Mengetahui besarnya pengaruh faktor Dukungan Atasan terhadap Kemandegan Karir Guru IPS SMA/ MA/ SMK Negeri di Kota Tegal?

\section{METODE PENELITIAN}

Penelitian ini menggunakan pendekatan korelasional asosiatif dengan metode yang bersifat ex post facto. Populasi sekaligus sampel pada penelitian ini adalah guru IPS SMAN/MAN/SMK Negeri yang berstatus pegawai negeri sipil yang berjumlah 59 orang dari 5 SMA Negeri, 1 MAN dan 3 SMK Negeri di Kota Tegal, (sumber Dinas Pendidikan Kota Tegal, 2015). Adapun kriteria untuk populasi yang terpilih adalah Guru dengan status pegawai negeri sipil yang kepangkatannya terhenti pada golongan IV/a dan sudah tertunda lebih dari 8 tahun/ tidak naik ke golongan IV/b. 
Angket, pedoman wawancara dan dokumentasi digunakan sebagai alat pengumpul data kemudian dianalisis setelah melakukan perhitungan statistik menggunakan SPSS. Dalam penelitian ini analisis regresi yang digunakan sebagai model untuk memprediksi hubungan antara satu variabel dependen dengan beberapa variabel independen. Selanjutnya dengan Uji F untuk mengetahui secara keseluruhan pengaruh dari semua faktor-faktor yang diduga mempengaruhinya.

\section{HASIL}

\section{Statistik Deskriptif Variabel}

Untuk memberikan gambaran mengenai variabel-variabel penelitian (Motivasi, Lingkungan Kerja dan Dukungan Atasan) sebagai variabel bebas (X). Sedangkan Kemandegan Karir merupakan variabel terikat (Y) digunakan tabel frekuensi absolut yang menunjukkan kisaran teoretis, kisaran sesungguhnya, angka rata-rata dan standar deviasi yang disajikan dalam tabel berikut:

Tabel 1. Statistik Deskriptif Variabel

\begin{tabular}{|l|c|c|c|}
\hline \multicolumn{1}{|c|}{ Variabel } & Mean & Median & Modus \\
\hline Motivasi & 18.49 & 18 & 18 \\
Lingkungan Kerja & 18.59 & 18 & 17 \\
Dukungan Atasan & 19.12 & 19 & 19 \\
Kemandegan Karir & & & \\
\hline
\end{tabular}

Sumber : Data yang diolah

Sedangkan untuk menginteprestasikan tingkat hubungan variabel bebas dengan hasil statistik deskriptif disajikan pada tabel berikut:

Tabel 2. Pedoman untuk Menginteprestasikan tingkat hubungan Variabel

\begin{tabular}{|c|c|l|}
\hline No & Kelas Interval & \multicolumn{1}{|c|}{ Tingkat Hubungan } \\
\hline 1 & $>33$ & Sangat Baik Sekali \\
\hline 2 & $30-33$ & Baik Sekali \\
\hline 3 & $26-29$ & Baik \\
\hline 4 & $22-25$ & Cukup \\
\hline 5 & $18-21$ & Kurang \\
\hline 6 & $14-17$ & Sangat kurang \\
\hline 7 & $<14$ & Tidak ada sama sekali \\
\hline
\end{tabular}


Berdasarkan hasil rekapitulasi statistik deskriptif ditemukan bahwa Motivasi Guru dan dukungan atasan berada pada tingkat/ level "kurang", sedangkan untuk variabel lingkungan kerja guru justru berada pada posisi "sangat kurang". Hasil deskriptif ketiga variabel bebas terhadap variabel terikat ini menunjukkan adanya hubungan motivasi guru, lingkungan kerja dan dukungan atasan terhadap kemandegan karir guru.

\section{Analisis}

Setelah data dikatakan valid dan reliabel, maka semua variabel dapat digunakan dalam penelitian. Berikut ini hasil analisis regresi linier berganda antara variabel motivasi, lingkungan kerja dan dukungan atasan sebagai variabel yang mempengaruhi dan variabel kemandegan karir sebagai variabel yang dipengaruhi.

Tabel 3. Ringkasan Analisis Regresi Linier Berganda

Model Summary

\begin{tabular}{|l|r|r|r|r|}
\hline Model & $\mathrm{R}$ & R Square & \multicolumn{1}{|c|}{$\begin{array}{c}\text { Adjusted R } \\
\text { Square }\end{array}$} & $\begin{array}{l}\text { Std. Error of the } \\
\text { Estimate }\end{array}$ \\
\hline 1 & $.915^{\mathrm{a}}$ & .837 & .825 & .076 \\
\hline
\end{tabular}

a. Predictors: (Constant), Dukungan.Atasan, Lingkungan.Kerja, Motivasi,

Dari tabel tersebut, nilai $\mathrm{R}$ sebesar 0,915 menunjukkan korelasi ganda (motivasi, lingkungan kerja dan dukungan atasan) dengan kemandegan karir guru IPS SMA/MA/SMK Negeri di Kota Tegal. Nilai Adjusted R Square sebesar 0,825 menunjukkan besarnya peran atau kontribusi variabel motivasi, lingkungan kerja dan dukungan atasan mampu menjelaskan variabel kemandegan karir guru IPS SMA/MA/SMK Negeri di Kota Tegal sebesar 82,5\%. Sedangkan 17,5\% di jelaskan oleh sebab lain.

\section{Pengujian Hipotesis}

Rangkuman hasil uji hipotesis ini disajikan dalam tabel berikut: 
Tabel 4. Uji signifikansi simultan

ANOVAb

\begin{tabular}{|c|l|r|r|r|r|r|}
\hline \multicolumn{2}{|c|}{} & $\begin{array}{r}\text { Sum of } \\
\text { Squares }\end{array}$ & \multicolumn{1}{c|}{ Df } & $\begin{array}{r}\text { Mean } \\
\text { Square }\end{array}$ & F & \multicolumn{1}{c|}{ Sig. } \\
\hline \multirow{2}{*}{1} & Regression & 1.618 & 3 & .405 & 69.529 & $.000^{\mathrm{a}}$ \\
\cline { 2 - 7 } & Residual & .314 & 54 & .006 & & \\
\cline { 2 - 7 } & Total & 1.932 & 57 & & & \\
\hline
\end{tabular}

a. Predictors:(Constant), Dukungan.Atasan, Lingkungan.Kerja, Motivasi,

b. Dependent Variable: Kemandegan Karir

Hasil analisis berdasarkan uji $\mathrm{F}$ atau uji signifikansi simultan adalah motivasi guru, lingkungan kerja dan dukungan atasan secara simultan berpengaruh terhadap kemandegan karir guru diterima. Nilai signifikansi $0,000<0,05$ menjelaskan bahwa variabel motivasi guru, lingkungan kerja dan dukungan atasan secara bersama-sama berpengaruh terhadap kemandegan karir guru IPS SMA/MA/SMK Negeri di Kota Tegal.

Tabel 5. Uji T

Coefficients $^{\mathrm{a}}$

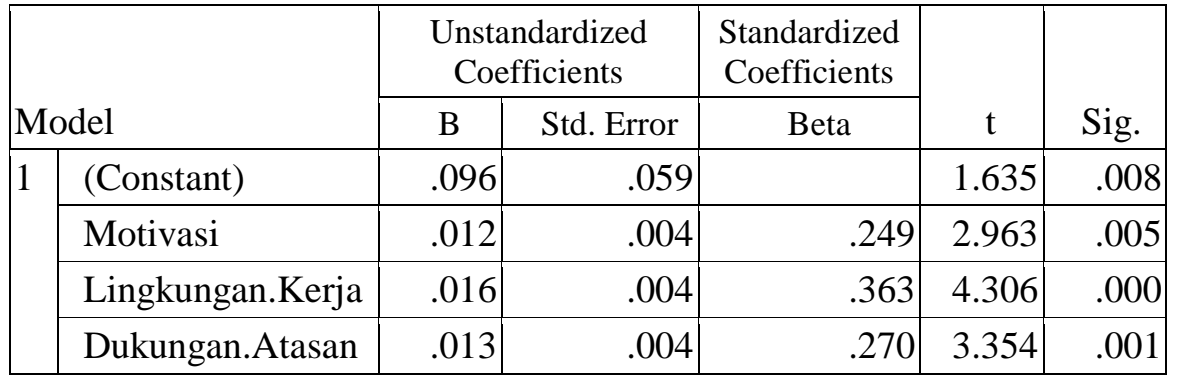

a. Dependent Variable: Kemandegan Karir

Hasil output SPSS dalam tabel 5 menunjukkan koefisien beta untuk motivasi guru adalah 0,249 ; lingkungan kerja guru sebesar 0,363 ; dukungan atasan sebesar 0,270 dengan taraf signifikansi lebih kecil 0,05. Hal ini menunjukkan bahwa secara parsial variabel independen berpengaruh signifikan terhadap variabel dependen yaitu kemandegan karir guru IPS SMA/MA/SMK Negeri di Kota Tegal.

Tabel 5 di atas menggambarkan persamaan regresi $\mathrm{Y}=0,096+$ $0,012 \mathrm{X} 1+0,016 \mathrm{X} 2+0,013 \mathrm{X} 3$. Constanta sebesar 0,096 menyatakan 
bahwa apabila tidak ada variabel bebas maka kemandegan karir guru hanya sebesar 0,096 saja. Sedangkan besar masing-masing tiap 1 kenaikan maka untuk motivasi guru akan meningkat sebesar 0,012; ; lingkungan kerja bertambah 0,016 dan dukungan atasan akan bertambah sebesar 0,013 .

\section{PEMBAHASAN}

Analisis berikut merupakan jawaban dari rumusan masalah yang diformulasikan dalam hipotesis sebagai berikut:

1. Dari uji ANOVA atau $F$ test, didapat $F$ hitung sebesar 69.529 dengan tingkat probabilitas 0.000 (signifikansi). Probabilitas jauh lebih kecil dari 0,05, maka model regresi dapat dikatakan bahwa independent variable yaitu motivasi guru, lingkungan kerja dan dukungan atasan secara simultan berpengaruh terhadap Kemandegan Karir Guru IPS SMA/MA/SMK Negeri di Kota Tegal..

2. Berdasarkan tabel 5 motivasi guru dinyatakan berpengaruh terhadap Kemandegan Karir Guru IPS SMA/MA/SMK Negeri di Kota Tegal.. Apabila motivasi guru untuk mengembangkan karirnya baik maka akan menekan kemandegan Karir.

3. Berdasarkan tabel 5 lingkungan kerja dinyatakan mempengaruhi Kemandegan Karir Guru IPS SMA/MA/SMK Negeri di Kota Tegal. Apabila lingkungan kerja nyaman dan kondusif untuk melakukan aktivitas kerja, maka akan menekan Kemandegan Karir Guru. Artinya karir guru yang semula masih berada pada pangkat/ golongan IV/a dapat dikurangi seiring semakin meningkatnya guru yang memiliki pangkat/ golongan IV/b.

4. Berdasarkan tabel 5 dukungan atasan mempengaruhi Kemandegan Karir Guru IPS SMA/MA/SMK Negeri di Kota Tegal. Apabila atasan mampu mengakomodir kebutuhan pegawainya serta dapat memfasilitasi sesuai kemampuan dan kebutuhan, maka akan menekan Kemandegan Karir Guru.

\section{KESIMPULAN DAN SARAN \\ Kesimpulan}

1. Pengujian secara bersama-sama menunjukkan hasil yang signifikan. Dengan demikian motivasi guru, lingkungan kerja dan dukungan atasan secara simultan berpengaruh terhadap kemandegan karir guru IPS SMA/MA/SMK Negeri di Kota Tegal.

2. Motivasi guru berpengaruh terhadap kemandegan karir guru IPS SMA/MA/SMK Negeri di Kota Tegal. 
3. Lingkungan kerja berpengaruh terhadap kemandegan karir guru IPS SMA/MA/SMK Negeri di Kota Tegal.

4. Dukungan atasan berpengaruh terhadap kemandegan karir guru IPS SMA/MA/SMK Negeri di Kota Tegal.

\section{Saran}

Berdasarkan temuan hasil penelitian, peneliti mengajukan saran kepada Dinas Pendidikan Kota Tegal, hendaknya menghimbau kepada guru-guru dalam rangka tertib administrasi, pengembangan sikap profesionalisme sehingga guru termotivasi untuk mengembangkan kariernya dengan baik. Selain itu juga dapat mensinergikan faktor-faktor yang telah terbukti berpengaruh positif dan signifikan (motivasi, lingkungan kerja dan dukungan atasan) terhadap kemandegan karir guru SMA/MA/SMK Negeri di Kota Tegal.

Kepada para akademisi dan peneliti, disarankan untuk melakukan penelitian lanjutan dengan populasi yang lebih luas dan melibatkan faktorfaktor lain yang mungkin dapat mempengaruhi kemandegan karir guru.

\section{DAFTAR PUSTAKA}

Allen, T.D at all. 1999 Belajar dan Pengembangan Job Content Plateauing dalam Perilaku Organisasi terjemahan Gina Gania. Learning and Development of Job Content Plateauing Organizational Behaviour 1980 Jakarta: Erlangga

Belly, Ellya dkk. 2006. Pengaruh Motivasi terhadap Minat Mahasiswa Akuntasi. Simposium Nasional Akuntasi 9 Padang.

Chenhall, R.H.(2004). The rule of cognitif and affective conflict in early implementation of activity-based cost management. Behavioral research in accounting, 16:19.

E Mulyasa. (2008). Menjadi Guru Profesional. Bandung: PT Remaja Rosdakarya

Handoko, Hani T. 2001 Manajemen Sumber Daya Manusia Edisi 2 Yogyakarta: BPFE

http://kamusbahasaindonesia.org/pendidikan/mirip\#ixzz30PHtzWVW

http://pmbisa.blogspot.com/2013/07/pengertian-guru-menurut-para-ahliperan.html

http://edukasi.kompasiana.com/2014/03/03/

Muhtar. (1992) Pedoman Bimbingan Guru dalam Proses Belajar Mengajar. Jakarta: PGK \& PTK Dep.Dikbud

I Nyoman Bagus Tri Permana Putra (2014). Analisis Faktor yang Mempengaruhi Career Plateau (kemandegan karir) Guru Pada SMPN 1 Denpasar. Jurnal Undiksha 
Oemar Hamalik (2004) Proses Belajar Mengajar. Jakarta: Bumi Aksara

Peraturan Menteri Negara Pendayagunaan Aparatur Negara Dan Reformasi

Birokrasi Nomor 16 tahun 2009 tentang Jabatan Fungsional Guru dan Angka Kreditnya

Purwanta, Edi. Faktor yang Mempengaruhi Eksplorasi Karier Siswa SLTP: Jurnal FIP UNY

Samosir, Marten. 1992. Seni Berpikir Kreatif. Jakarta: Erlangga

Santoso. 2007. Pengaruh Pemberdayaan Kerja, Dukungan atasan , Budaya Organisasi Terhadap Kinerja Pegawai Dinas Kelautan dan Perikanan Provinsi Jawa Tengah. Thesis Universitas Semarang

Sekaran, Uma. 2006. Research Methods for Bussiness (Metodologi Penelitian untuk Bisnis). PT. Salemba Emapat, Jakarta.

Shield, M.D, \& S. M. Young, 1989. Behavioral model for implementing cost management system.Journal of cost management(Winter).

Simamora H. 2001 Manajemen Sumber Daya Manusia Edisi 2 Jogjakarta Badan Penerbit STIE YKPN

Studer, Jeannine R. 2005. The Profesional School Councelor: an advocate for Student. Belmont, CA: Thomson Brooks/ Cole

Supranto, J. (2004). Statistik: Teori dan Aplikasi Edisi keenam. Jakarta: Erlangga

Syaiful Sagala (2009) Kemampuan Profesional Guru Dan Tenaga Kependidikan. Bandung : ALFABETA.

Taveira, dkk. 2003 "Guidance Theory And Practice: The Status of Career Exploration", British Journal of Guidance and Counseling Vo.31. 2 Undang-undang Nomor 14 Tahun 2005 tentang Guru dan Dosen Undang-undang Nomor 20 Tahun 2003 tentang Sistem Pendidikan Nasional 